\title{
Effect of Fertilizer and Drying Methods on Seed Germination of Okra (Abelmoschus esculentus L.) Cultivars at Different Harvesting Times
}

\author{
Ghadir Mohammadi ${ }^{1}$, Ebrahim. M. Khah ${ }^{1}$, Spyridon A. Petropoulos ${ }^{1}$, Garip Yarsi ${ }^{2}$ \& Apostolos Vlasakoudis ${ }^{1}$ \\ ${ }^{1}$ University of Thessaly, School of Agricultural Sciences, Crop Production and Rural Environment, Volos, Greece \\ ${ }^{2}$ Adiyaman University Plant and Animal Production, Adiyaman, Turkey \\ Correspondence: Ebrahim. M. Khah, University of Thessaly, School of Agricultural Sciences, Crop Production \\ and Rural Environment, Volos, Greece. Tel: 30-2421-093-138. E-mail: ekhah@uth.gr
}

Received: November 19, 2012 Accepted: February 16, 2013 Online Published: March 15, 2013

doi: $10.5539 /$ jas.v5n4p1

URL: http://dx.doi.org/10.5539/jas.v5n4p1

\begin{abstract}
Okra hardseedness results in slow and uneven germination. This study determined the effects of fertilizer application and drying methods on hardseedness breakdown of okra (Abelmoschus esculentus L.) cultivars (cv. Boyiatiou', 'Veloudo', 'Clemson' and 'Pylias'). Three fertilizer level (150, 300 and $450 \mathrm{mg} \mathrm{L}^{-1} \mathrm{~N}$ ) and two different drying methods (seeds and pods) were applied. The results showed that by increasing $\mathrm{N}$ application from 150 to $450 \mathrm{mg} \mathrm{L}^{-1} \mathrm{~N}$ increased seed germination regardless of drying method, whereas the application of $450 \mathrm{mg} \mathrm{L}^{-1} \mathrm{~N}$ resulted in the higher seed germination percentage, regardless of cultivar and drying method. In addition, harvesting seeds at 40 days after flowering (DAF) resulted in an increase of germination rate, especially when $450 \mathrm{mg} \mathrm{L}^{-1} \mathrm{~N}$ were applied. Seed germination of seeds harvested at 40 to 50 days after flowering (DAF) was reduced, especially when seed drying instead of pod drying was applied. However, for cv. 'Boyiatiou' the application of $150 \mathrm{mg} \mathrm{L}^{-1} \mathrm{~N}$ resulted in higher percentage of hard seeds and lower seed germination rate, whereas pod drying reduced the occurrence of hardseedness. For all cultivars, seeds from the middle part of the plant had a higher seed germination percentage at $450 \mathrm{mg} \mathrm{L}^{-1} \mathrm{~N}$ level, regardless of drying methods. In conclusion, increasing the $\mathrm{N}$ application rate up to $450 \mathrm{mg} \mathrm{L}^{-1}$, harvesting seeds at $40 \mathrm{DAF}$ and collecting seeds from the middle part of the plant could be a useful means for reducing the occurrence of hardseedness and increasing germination percentage of okra seeds.
\end{abstract}

Keywords: drying method, fertilizer, germination, hardseedness, okra

\section{Introduction}

Okra (Abelmoschus esculentus (L.) Moench) is one of the most important summer vegetables of the tropical and subtropical world, grown for its immature pods. The crop is propagated through seed, which loses its viability quickly (Thakur \& Arora, 1993). Okra is a heat loving plant of Malvaceae family (Saif et al., 2008).

Seed germination and dormancy are two adaptive traits in plants under the influence of genetic and environmental factors. Seed germination can be defined as the potential of a seed lot to germinate under defined conditions (Black et al., 2006), whereas dormancy is the absence of germination of a seed under optimal conditions (Hilhorst \& Toorop, 1997). Dormancy is classified as endogenous and exogenous dormancy (Copeland \& McDonald, 2001). Endogenous dormancy is imposed by embryo or other inhibitor components inside the seed while exogenous dormancy is attributed to the seed coat. Seed coverings that impose exogenous dormancy are the endosperm, perisperm, seed coat integuments, or fruit pericarp (Geneve, 1998). The most common form of exogenous dormancy occurs when seed coats become suberized and impermeable to water, which is commonly known as hardseededness and is typical of many species from families such as Fabaceae, Malvaceae, Chenopodiaceae and Liliaceae (Geneve, 1998; Copeland \& McDonald, 2001).

Okra (Abelmoschus esculentus (L.) Moench) plants exhibit seed hardness that complicates their management. Seed hardness interferes with seed germination, weed control, harvesting and other management factors (Mohammadi et al., 2011). Tough seed coats may regulate germination by establishing a permeability barrier that can interfere with the water uptake required for imbibition and subsequent radicle emergence; for gaseous exchange, particularly oxygen uptake required for respiration; and/or for the outward diffusion of endogenous germination inhibitors (Mmolawa, 1987). Typical characteristics of hard seeds are seed coats having 
permeability to water but not to gases or vice versa (Budy et al., 1986; Mmolawa, 1987). Hardseededness can vary in a population of seeds. It is increased by environmental (dry) conditions during seed maturation, and seed storage (Baskin \& Baskin, 1998). It is reported that thick walls in some okra seeds delay germination; the seeds coats are often hard and the embryo can be slow to develop during germination. Consequently, treatments to seed coats which overcome hardseededness are generally required for germination (El Balla et al., 2011). Egley and Elmore (1987) also reported that hard seed coat is of major importance for okra seed dormancy. Luis Felipe et al. (2010) reported that the occurrence of hardseedness and the low percentage of seed germination are major challenges in growing okra. The percentage of seed germination of okra is frequently low, due to tegument impermeability and is the major barrier to the emergence of okra seeds for commercial producers. The percentage of hardseedness varies among the cultivars (Ellis et al., 1985; Standifer et al., 1989), with some cultivars not having hardseedness or having a low percentage of hard seeds that doesn't impose any impedance on their germination, whereas for other cultivars the high percentage of hard seeds does not allow them to germinate, or allows only for low germination percentage (El Balla et al., 2011).

Several factors such as the time of harvest of pods, the seed moisture content, the fertilizer and growth regulators application, the priming and scarification of seeds are some of the methods proposed to affect okra hardseedness. The percentage of hardseedness was increased significantly in all cultivars with the increase in the maturity of seeds and was attributes to the deposition or development of hard cuticle or impermeable cell layer of the seed coat during the later stages of seed development (El Balla et al., 2011). Chauhan and Bhandri (1971) reported that okra seeds harvested at 30 days from anthesis had the maximum percentage of germination. Similar findings were reported by El Balla et al. (2011), who proposed that germination of okra seeds was the maximum at 27 to 30 days after anthesis. Castro et al. (2008) also concluded that okra seeds harvested at 34 and 41 DAA had the highest germination. In contrast, Demir (1997) reported that okra seeds failed to germinate until 32 DAA, and the highest germination percentage was observed when seeds were harvested at 39 and 43 days after anthesis. Setubal et al. (1994) observed that the proportion of hard seeds increased significantly when the harvesting was delayed until the senescence of the plant. Passam et al. (1998) reported that premature or late harvesting of pods results in reduced seed germination.

Similarly, seed moisture content has also a significant effect on hardseedness, as with the maturity process the seed moisture content decreases and the percentage of hardseedness increases. Similar results have also been reported by other researchers (Quinlivan, 1971; Ellis et al., 1985; Standifer et al., 1989; Demir, 2001; El Balla et al., 2011). El Balla et al. (2011) reported that seeds of Hibiscus esculentus L. (Moench.) with 13\% moisture content tend to show little or no hardseededness, but once the seeds have been dried and their moisture content has dropped to 4-6\%, hardseedness percentage increase significantly. Demir (1997) reported that the moisture content of seeds when harvested at 50 days after anthesis dropped to $10 \%$ with a percentage of $52 \%$ of hard seeds. El Balla et al. (2011) also showed that when the seed moisture content of Trifolium patense, Trifolium repens and Lupinus arborcus dropped to $14 \%$, the percentage of hard seeds increased.

Pod position can also affect hardseedness, with seeds harvested from pods in the middle and lower part of the plant having higher germination percentage and lower percentage of hard seeds than those harvested from the upper part of the plant. Luis Felipe et al. (2010) and Malik et al. (2000) reported that seeds from pods located in the middle part of the plant had higher germination, whereas in contrast Prabhakar et al. (1985), Malik et al. (2000), Yadav and Dhankhar (2001) and Naik et al. (2004), reported seeds harvested from the lower pods had higher germination percentage.

Okra has been found to show good response to different plant nutrients (Mishra \& Singh, 2005). Lenka et al. (1989) evaluated the $\mathrm{N}\left(0,50,75\right.$, and $\left.100 \mathrm{Kg} \mathrm{ha}^{-1}\right)$ and P levels $\left(30\right.$ and $\left.60 \mathrm{Kg} \mathrm{h}^{-1}\right)$ with constant $\mathrm{K}$ on okra cv. Parbhanikranti and found significant effects on yield and its attributes. Anjum and Amjad (1999) applied various doses of N, P and K fertilizers to okra plants cv. Pusa Sawani. Seed germination was not affected by the fertilizer application while plant height, number of leaves per plant, number of pods per plant, pod length and green pod yield were the highest at the highest dose of fertilizer $\left(125 \mathrm{Kg} \mathrm{N}_{1} 100 \mathrm{Kg} \mathrm{P}_{2} \mathrm{O}_{5}\right.$ and $\left.80 \mathrm{Kg} \mathrm{K}_{2} \mathrm{O} \mathrm{ha}^{-1}\right)$. In contrast, Muhammad et al. (2001) reported that germination percentage of okra cv. Pusa Sawaniit, green pod length and yield were not affected by the application of various levels of fertilizers.

The aim of the present study was to determine the effect of fertilizer application in relation to different harvesting times, the part of the plant and the methods of seed drying on seed germination percentage in order to propose useful means to overcoming hardseedness of different okra cultivars. 


\section{Material and Methods}

The experiment was conducted at the Agricultural Farm of the University of Thessaly, Greece during 2011. Climate conditions and soil structure characteristics of the experimental site are presented in Figure 1 and Table 1 respectively. Each experiment was laid out in Randomized Complete Block Design with factorial arrangement using three replications. The experiment treatments consisted of four different cultivars of okra (cv. 'Clemson', 'Boyiatiou', 'Veloudo' and 'Pylias'), three fertilizer levels $\left[\mathrm{F}_{1}=\operatorname{control}\left(150 \mathrm{mg} \mathrm{L}^{-1} \mathrm{~N} ; 150 \mathrm{mg} \mathrm{L}^{-1} \mathrm{P} ; 150 \mathrm{mg} \mathrm{L}^{-1}\right.\right.$ $\left.\mathrm{K}) ; \mathrm{F}_{2}=300 \mathrm{mg} \mathrm{L}^{-1} \mathrm{~N} ; 150 \mathrm{mg} \mathrm{L}^{-1} \mathrm{P} ; 150 \mathrm{mg} \mathrm{L}^{-1} \mathrm{~K} ; \mathrm{F}_{3}=450 \mathrm{mg} \mathrm{L}^{-1} \mathrm{~N} ; 150 \mathrm{mg} \mathrm{L}^{-1} \mathrm{P} ; 150 \mathrm{mg} \mathrm{L}^{-1} \mathrm{~K}\right]$ and two drying methods (fast drying-seed drying and slow drying-pod drying). Fertilizers were applied to the plants on a weekly basis through irrigation water (Fertilizer sources were: N: Yara Italia S.p.A., P: Tessenderlo Chemie NV/SA, K: DEM. S. Gavriel \& Co LTD companies).

Table 1. Soil structure characteristics of experimental field

\begin{tabular}{llllll}
\hline Soil & $\mathrm{S}$ & $\mathrm{Si}$ & $\mathrm{C}$ & $\mathrm{pH}$ & Organic Matter \\
\cline { 2 - 6 } Structure & $48 \%$ & $29 \%$ & $23 \%$ & $7.7-8.1$ & $1.3 \mathrm{gr} / 100 \mathrm{gr}$ Soil \\
\hline
\end{tabular}

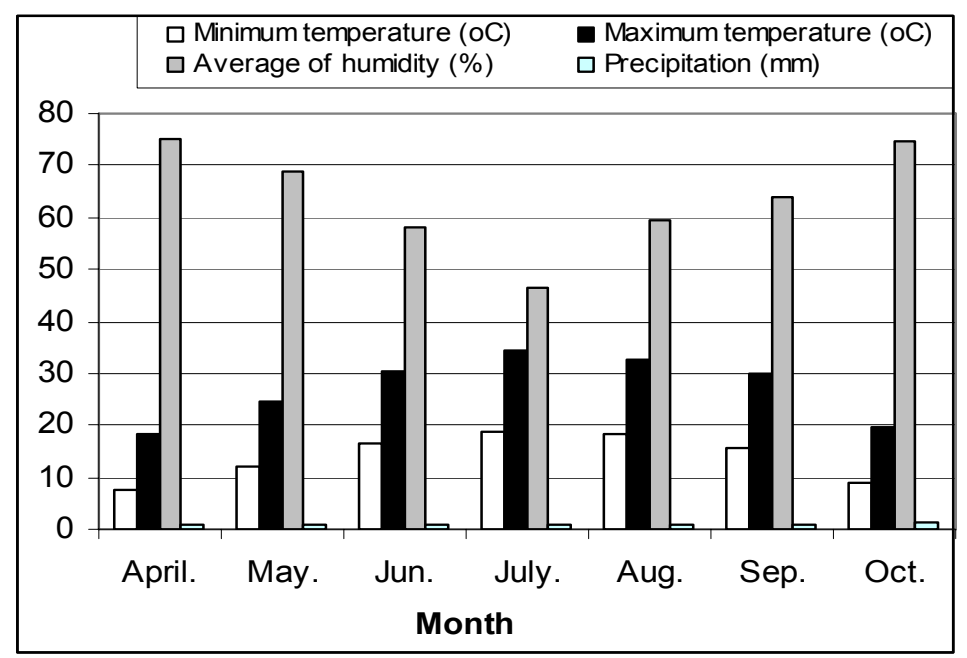

Figure 1. Climate conditionsof experimental location

Stock solutions of the three fertilizers were dissolved in $150 \mathrm{~L}$ barrels and each week plants of the various treatments were fertilized with $0.5 \mathrm{~L}$ of each solution.

Land preparation process, such as plowing, disk and trowel, was completed according to crop requirements and prior to transplantation, which was carried out during the first half of May and when seedlings reached a height of $10 \mathrm{~cm}$. Transplantation was completed in June 10, 2011 about 20 days after seed sowing. Each replication was comprised of 12 plots of $9 \mathrm{~m}^{2}$ each $(3 \times 3 \mathrm{~m})$. Crop was irrigated regularly on a weekly basis. Broadleaves weeds were controlled via hoeing manually and narrow leaves by Fusilade herbicide (a.i. fluazifop-P-butil @ 800 ml/1000 m²). Plants were tagged 26 days after transplantation and when the first flowers appeared. Pods were collected at four different harvesting times i.e. 30, 35, 40 and 50 days after flowering (DAF).

Each individual okra plant was divided in three parts (lower, low to middle and upper part) and pods were tagged according to the part of the plant. Pods from each part of the plant were collected and dried by applying either seed drying (fast drying) or pod drying (slow drying). For seed drying method, after harvesting, seeds were removed from pods, while for pod drying method, pods, were dried at room temperature for 15 days after harvesting and thereafter seeds were removed from pods. Initial seed moisture content was calculated by using the low constant temperature oven method (ISTA, 2009) and using the following formula:

$$
\% M C=\frac{(M 2-M 3)}{(M 2-M 1)} \times 100
$$


where $\mathrm{M}_{1}=$ Weight in grams of the container and its cover,

$\mathrm{M}_{2}=$ Weight in grams of the container, its cover and ground material before drying,

$\mathrm{M}_{3}=$ Weight in grams of container, its cover and ground material after drying.

In order to study the hardseedness, seed germination test was conducted using 400 seeds in total, with four replications per treatment of 100 seeds each (International Seed Testing Association [ISTA], 2009). Seeds were considered germinated when the tip of the radical had grown free of the seed coat (Wiese \& Binning, 1987; Auld et al., 1988). Seeds that could not germinate due to low water absorption were considered as hard seeds. Germination percentage was calculated by thefollowing formula (ISTA, 2009):

$$
\text { Germination (\%) } \frac{\text { Number of seeds germinated }}{\text { Number of seeds tested }} \times 100
$$

Statistical analysis was carried out with the aid of the S.A.S. statistical package (SAS Institute Inc., USA) and mean comparison according to Duncan Multiple Range Test (DMRT) at $\mathrm{p}<0.05$. Graphs were generated by using Microsoft Excel software (Microsoft Corporation, USA).

\section{Results and Discussion}

\subsection{Effect of Fertilizer Application on Okra Seeds Germination}

Seed germination increased with increasing level of fertilizer from $150 \mathrm{mg} \mathrm{L}^{-1} \mathrm{~N}$ to $450 \mathrm{mg} \mathrm{L}^{-1} \mathrm{~N}$ for both drying methods (Figure 2). Between the drying methods, higher percentage of germination (71.0\%) was observed when $450 \mathrm{mg} \mathrm{L}^{-1} \mathrm{~N}$ and pod drying method were applied, comparing to seed drying method and $150 \mathrm{mg} \mathrm{L}^{-1} \mathrm{~N}(59.6 \%)$ (Figure 2). In contrast, Amjad et al. (2001) reported that seed germination percentage of okra cv. Pusa Sawaniit was not affected by the application of different levels of fertilizers, indicating that seed germination is genotype depended.

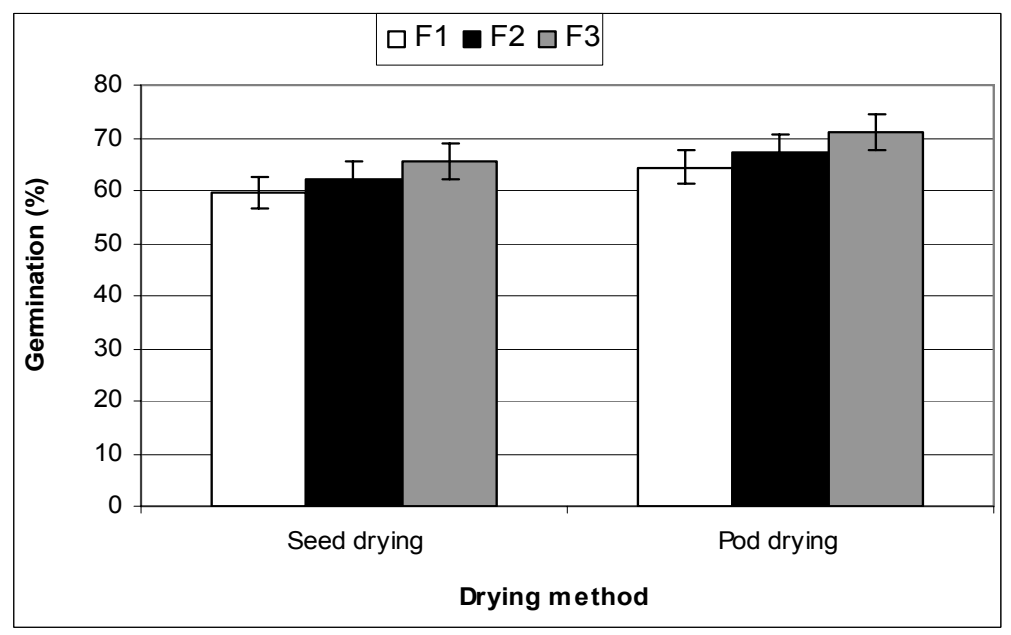

Figure 2. Effect of fertilizer and drying method on seed germination

Therefore, in order to enhance germination of okra seeds of the cultivars tested in the present study, the application of $450 \mathrm{mg} \mathrm{L}^{-1} \mathrm{~N}$ and pod drying is essential.

\subsection{Effect of Fertilizer and Harvesting Times on Seed Germination}

The study of the effect of fertilizer application on germination percentage of seeds harvested at different times showed that for both drying methods the application of $450 \mathrm{mg} \mathrm{L}^{-1} \mathrm{~N}$ and harvesting at 40 days after flowering (DAF) resulted in higher germination percentage (Figures 3 and 4). For cv. 'Boyiatiou', harvesting seeds at 50 days after flowering (DAF) and from the lower part of the plant resulted in lower seed germination percentage and more hard seeds than the other cultivars (Table 2). The germination percentage of seeds harvested from 40 to 50 days after flowering (DAF) reduced, especially when seed drying method instead of pod drying was applied (Figure 3 and 4). 
Table 2. Effect of fertilizer on seed germination percentage forcv. 'Boyiatiou' in relation to drying method and time of harvest

\begin{tabular}{|c|c|c|c|c|c|c|c|c|c|}
\hline & & & & & & & \multicolumn{3}{|c|}{ Cultivar: Boyiatiou } \\
\hline Plant part & Lower & & & & & & & & \\
\hline Drying method & $\mathrm{D}_{1}$ & & & $\mathrm{D}_{2}$ & & & $\mathrm{~F}_{1}$ & $\mathrm{~F}_{2}$ & $\mathrm{~F}_{3}$ \\
\hline Pod harvesting time & $\mathrm{F}_{1}$ & $\mathrm{~F}_{2}$ & $\mathrm{~F}_{3}$ & $\mathrm{~F}_{1}$ & $\mathrm{~F}_{2}$ & $\mathrm{~F}_{3}$ & $\mathrm{D}_{1} * \mathrm{D}_{2}$ & $\mathrm{D}_{1} * \mathrm{D}_{2}$ & $\mathrm{D}_{1} * \mathrm{D}_{2}$ \\
\hline $30 \mathrm{DAF}$ & $40.3^{\mathrm{c}}$ & $40.3^{\mathrm{c}}$ & $43.7^{\mathrm{c}}$ & $46^{\mathrm{c}}$ & $45.3^{\mathrm{b}}$ & $46^{\mathrm{c}}$ & ns & ns & ns \\
\hline $35 \mathrm{DAF}$ & $48^{\mathrm{b}}$ & $50^{\mathrm{b}}$ & $57.3^{b}$ & $54.7^{\mathrm{b}}$ & $57.3^{\mathrm{b}}$ & $62.3^{\mathrm{b}}$ & ns & ns & ns \\
\hline $40 \mathrm{DAF}$ & $67^{\mathrm{a}}$ & $64^{\mathrm{a}}$ & $78.7^{\mathrm{a}}$ & $73.3^{\mathrm{a}}$ & $75.3^{\mathrm{a}}$ & $85.7^{\mathrm{a}}$ & ns & ns & ns \\
\hline $50 \mathrm{DAF}$ & $39.7^{\mathrm{c}}$ & $42^{\mathrm{c}}$ & $42.3^{\mathrm{c}}$ & $44.3^{\mathrm{c}}$ & $59.3^{\mathrm{ab}}$ & $59.3^{\mathrm{b}}$ & $\mathrm{ns}$ & ns & $*$ \\
\hline Average & 48.7 & 49.0 & 55.5 & 54.5 & 59.3 & 63 & & & \\
\hline
\end{tabular}

$\mathrm{D}_{1}$ : Seed drying method; $\mathrm{D}_{2}$ : Pod drying method, DAF: Days after flowering. $\mathrm{F}_{1}=$ control $\left(150 \mathrm{mg} \mathrm{L}^{-1} \mathrm{~N} ; 150 \mathrm{mg}\right.$ $\left.\mathrm{L}^{-1} \mathrm{P} ; 150 \mathrm{mg} \mathrm{L}^{-1} \mathrm{~K}\right) ; \mathrm{F}_{2}=300 \mathrm{mg} \mathrm{L}^{-1} \mathrm{~N} ; 150 \mathrm{mg} \mathrm{L}^{-1} \mathrm{P} ; 150 \mathrm{mg} \mathrm{L}^{-1} \mathrm{~K} ; \mathrm{F}_{3}=450 \mathrm{mg} \mathrm{L}^{-1} \mathrm{~N} ; 150 \mathrm{mg} \mathrm{L}^{-1} \mathrm{P} ; 150 \mathrm{mg} \mathrm{L}^{-1}$ $\mathrm{K}$.

ns: non- significant; * significant at 5-\% $(\mathrm{P}<0.05)$.

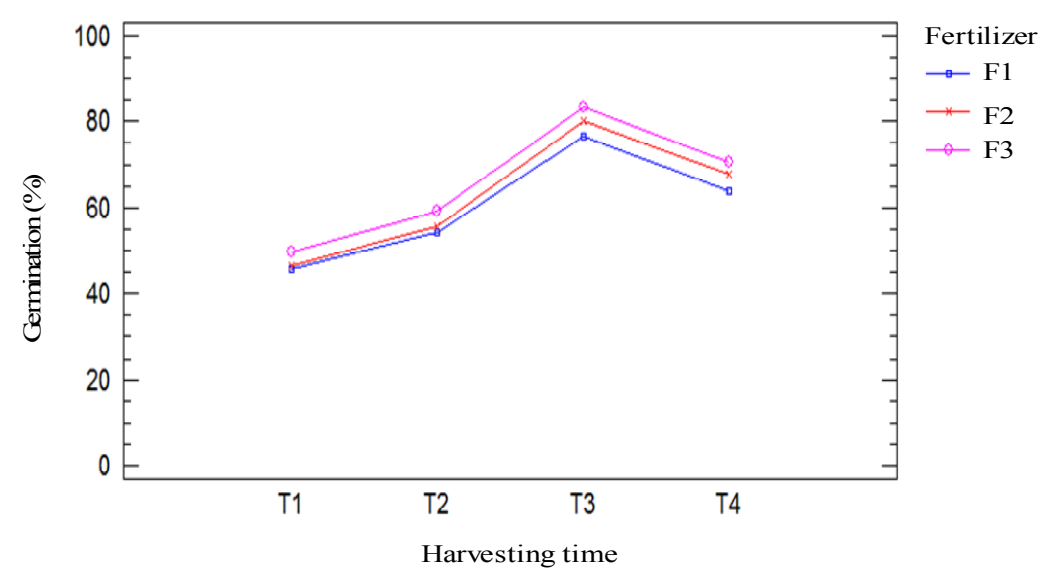

Figure 3. Effect of fertilizer and harvesting timeon seed germination percentage for seed drying method

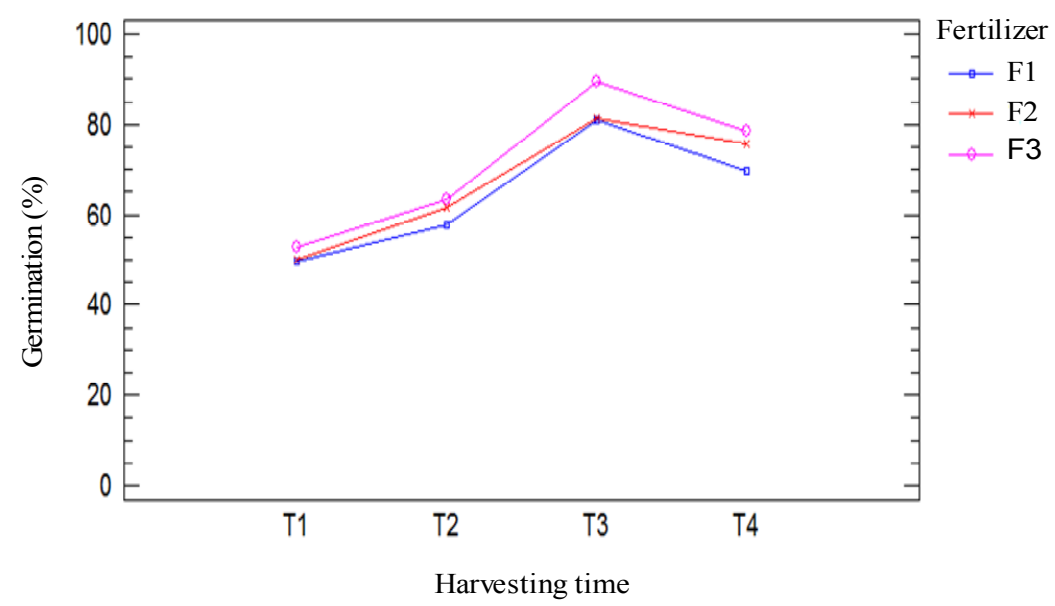

Figure 4. Effect of fertilizer and harvesting timeon seed germination percentage for pod drying method 
El Balla et al. (2011) also reported that okra seeds harvested at 39 and 43 days after anthesis (DAA) had higher seed germination. Several studies suggesting that seed germination is the highest when pods are harvested at 35 days (Ewete, 1980; Kanwar \& Saimbhi, 1987) and 40 days after anthesis (Neupane et al., 1991), whereas a delay in harvesting resulting in reduced seed weight and germination percentage.

Regarding seed moisture content, seeds harvested at 30 days after flowering (DAF) and dried by seed drying method had higher moisture content, whereas delay in harvesting resulted in reduced moisture content of seeds (Table 3). In addition, seeds harvested at 50 days after flowering (DAF) and dried by seed drying method had the lowest moisture content, comparing to the other harvesting times and drying methods (Table 3 ).

Table 3. Effect of fertilizer andharvesting time on moisture contentpercentage (MC) in relation to drying methodsand timeof harvest

\begin{tabular}{llll}
\hline Fertilizer & Harvesting time & Seed drying MC\% & Pod drying MC \% \\
\hline $\mathrm{F}_{1}$ & $\mathrm{~T}_{1}$ & 39.2 & 11.4 \\
& $\mathrm{~T}_{2}$ & 27.4 & 11.5 \\
& $\mathrm{~T}_{3}$ & 43.8 & 10.9 \\
& $\mathrm{~T}_{4}$ & 13.9 & 10.8 \\
$\mathrm{~F}_{2}$ & $\mathrm{~T}_{1}$ & 39.2 & 12.2 \\
& $\mathrm{~T}_{2}$ & 30.1 & 12.2 \\
& $\mathrm{~T}_{3}$ & 42.0 & 11.0 \\
& $\mathrm{~T}_{4}$ & 14.9 & 11.4 \\
$\mathrm{~F}_{3}$ & $\mathrm{~T}_{1}$ & 35.1 & 11.4 \\
& $\mathrm{~T}_{2}$ & 28.4 & 11.4 \\
& $\mathrm{~T}_{3}$ & 44.5 & 11.6 \\
& $\mathrm{~T}_{4}$ & 15.2 & 12.6 \\
\hline ANOVA & 20.6 & 16.6 \\
Main effects & 17013.1 & 6.7 \\
Fertilizer (F) & 103.1 & 11.4 \\
Harvesting Time (T) & & \\
Interactions (FxT) & &
\end{tabular}

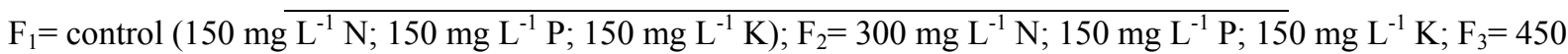
$\mathrm{mg} \mathrm{L}^{-1} \mathrm{~N} ; 150 \mathrm{mg} \mathrm{L}^{-1} \mathrm{P} ; 150 \mathrm{mg} \mathrm{L}^{-1} \mathrm{~K}$. $\mathrm{T}_{1}=$ Harvesting pods 30 days after flowering (DAF); $\mathrm{T}_{2}=\mathrm{Harvesting} \mathrm{pods}$ 35 days after flowering (DAF); $\mathrm{T}_{3}=$ Harvesting pods 40 days after flowering (DAF); $\mathrm{T}_{4}=$ Harvesting pods 50 days after flowering (DAF).

Pods harvested before full maturity have higher moisture content, since moisture content decreases with maturity process. Therefore, it seems that seed moisture content is an important factor for the development of hard seeds (El Balla et al., 2011). When immature okra fruits were harvested, the amount of dry matter of such fruits was very low, and seeds of these fruits were not able to germinate. Setubal et al. (1998) reported that the quality of okra seeds was affected by the interaction of fruit age, drying method and drying conditions. The highest values for germination percentage observed when seeds were harvested at 45 to 55 days after anthesis (up to $92 \%$ germination) and the percentage of hard seeds was not affected by the drying method and drying conditions. The seeds from fruits harvested at 35 and 45 days after anthesis had higher germination percentage when dried inside the fruit in natural environment.

\subsection{Effect and Fertilizer and Harvesting Time on Cultivar Seed Germination}

The effect of fertilizer application on seed germination percentage varied among the cultivars tested in the present study. The application of $450 \mathrm{mg} \mathrm{L}^{-1} \mathrm{~N}$ on all cultivars and for both drying methods resulted in higher percentage of seed germination (Figures 5 and 6). Seeds of cv. 'Boyiatiou' had lower seed germination 
percentage and higher percentage of hard seeds in comparison to other cultivars when $150 \mathrm{mg} \mathrm{L}^{-1} \mathrm{~N}$ were applied, although pod drying method resulted in lower percentage of hardseedness than seed drying method (Figures 5 and 6). The application of $450 \mathrm{mg} \mathrm{L}^{-1} \mathrm{~N}$, combined with seed drying method was more beneficial for cv. 'Veloudo', especially when pods were harvested from the middle part of the plant $(65 \%$ seed germination percentage) (Table 4). Similarly, the application of $450 \mathrm{mg} \mathrm{L}^{-1} \mathrm{~N}$ and pod drying method had a more profound effect for cv. 'Boyiatiou' and for pods harvested from the middle part of plant (Table 5), whereas increasing the fertilizer level from 150 to $450 \mathrm{mg} \mathrm{L}^{-1} \mathrm{~N}$, resulted in a decrease for seed germination percentage of seeds harvested from the upper part of the plant (Table 6).

Table 4. Effect of fertilizer on seed germination percentage of cv. 'Veloudo' in relation to drying method and time of harvest

\section{Cultivar: Veloudo}

\begin{tabular}{|c|c|c|c|c|c|c|c|c|c|}
\hline Plant part & Middl & & & & & & & & \\
\hline Drying method & $\mathrm{D}_{1}$ & & & $\mathrm{D}_{2}$ & & & $\mathrm{~F}_{1}$ & $\mathrm{~F}_{2}$ & $\mathrm{~F}_{3}$ \\
\hline Pod harvesting time & $\mathrm{F}_{1}$ & $\mathrm{~F}_{2}$ & $\mathrm{~F}_{3}$ & $\mathrm{~F}_{1}$ & $\mathrm{~F}_{2}$ & $\mathrm{~F}_{3}$ & $\mathrm{D}_{1} * \mathrm{D}_{2}$ & $\mathrm{D}_{1} * \mathrm{D}_{2}$ & $\mathrm{D}_{1} * \mathrm{D}_{2}$ \\
\hline $30 \mathrm{DAF}$ & $44.3^{\mathrm{d}}$ & $41.7^{\mathrm{c}}$ & $52.3^{\mathrm{d}}$ & $50^{\mathrm{d}}$ & $48.7^{\mathrm{c}}$ & $58^{\mathrm{d}}$ & ns & ns & $\mathrm{ns}$ \\
\hline $35 \mathrm{DAF}$ & $49.7^{\mathrm{c}}$ & $58.3^{\mathrm{b}}$ & $63^{\mathrm{c}}$ & $56^{\mathrm{c}}$ & $68.3^{\mathrm{b}}$ & $69.7^{\mathrm{c}}$ & ns & $\mathrm{ns}$ & $\mathrm{ns}$ \\
\hline $40 \mathrm{DAF}$ & $69^{\mathrm{a}}$ & $73 a$ & $76.3^{\mathrm{a}}$ & $77.3^{\mathrm{a}}$ & $85^{\mathrm{a}}$ & $88.7^{\mathrm{a}}$ & ns & ns & ns \\
\hline $50 \mathrm{DAF}$ & $55.7^{\mathrm{b}}$ & $57^{\mathrm{b}}$ & $68.7^{\mathrm{b}}$ & $65.3^{\mathrm{b}}$ & $65.7^{\mathrm{b}}$ & $75.3^{\mathrm{b}}$ & ns & ns & ns \\
\hline Average & 54.6 & 57.5 & 65.0 & 62.1 & 66.9 & 72.9 & & & \\
\hline
\end{tabular}

$\mathrm{D}_{1}$ : Seed drying method; $\mathrm{D}_{2}$ : Pod drying method, DAF: Days after flowering. $\mathrm{F}_{1}=\operatorname{control}\left(150 \mathrm{mg} \mathrm{L}^{-1} \mathrm{~N} ; 150 \mathrm{mg}\right.$ $\left.\mathrm{L}^{-1} \mathrm{P} ; 150 \mathrm{mg} \mathrm{L}^{-1} \mathrm{~K}\right) ; \mathrm{F}_{2}=300 \mathrm{mg} \mathrm{L}^{-1} \mathrm{~N} ; 150 \mathrm{mg} \mathrm{L}^{-1} \mathrm{P} ; 150 \mathrm{mg} \mathrm{L}^{-1} \mathrm{~K} ; \mathrm{F}_{3}=450 \mathrm{mg} \mathrm{L}^{-1} \mathrm{~N} ; 150 \mathrm{mg} \mathrm{L}^{-1} \mathrm{P} ; 150 \mathrm{mg} \mathrm{L}^{-1}$ $\mathrm{K}$.

ns: non- significant; * significant at 5-\% $(\mathrm{P}<0.05)$.

Table 5. Effect of fertilizer on seed germination percentage of cv. 'Boyiatiou' in relation to drying method and time of harvest

\begin{tabular}{|c|c|c|c|c|c|c|c|c|c|}
\hline & & & & & & & \multicolumn{3}{|c|}{ Cultivar: Boyiatiou } \\
\hline Plant part & Middl & & & & & & & & \\
\hline Drying method & $\mathrm{D}_{1}$ & & & $\mathrm{D}_{2}$ & & & $\mathrm{~F}_{1}$ & $\mathrm{~F}_{2}$ & $\mathrm{~F}_{3}$ \\
\hline Pod harvesting time & $\mathrm{F}_{1}$ & $\mathrm{~F}_{2}$ & $\mathrm{~F}_{3}$ & $\mathrm{~F}_{1}$ & $\mathrm{~F}_{2}$ & $\mathrm{~F}_{3}$ & $\mathrm{D}_{1} * \mathrm{D}_{2}$ & $\mathrm{D}_{1} * \mathrm{D}_{2}$ & $\mathrm{D}_{1} * \mathrm{D}_{2}$ \\
\hline $30 \mathrm{DAF}$ & $36.7^{\mathrm{b}}$ & $41^{\mathrm{c}}$ & $49^{\mathrm{bc}}$ & $45.3^{\mathrm{c}}$ & $46^{\mathrm{c}}$ & $51.7^{\mathrm{c}}$ & ns & ns & ns \\
\hline $35 \mathrm{DAF}$ & $49^{\mathrm{b}}$ & $54.7^{\mathrm{b}}$ & $61.3^{\mathrm{ab}}$ & $55^{\mathrm{b}}$ & $58.7^{\mathrm{b}}$ & $71.7^{\mathrm{ab}}$ & ns & ns & $\mathrm{ns}$ \\
\hline $40 \mathrm{DAF}$ & $63^{\mathrm{a}}$ & $67.3^{\mathrm{a}}$ & $71^{\mathrm{a}}$ & $69.7^{\mathrm{a}}$ & $75.7^{\mathrm{a}}$ & $79.7^{\mathrm{a}}$ & ns & ns & $\mathrm{ns}$ \\
\hline $50 \mathrm{DAF}$ & $40^{c}$ & $42^{c}$ & $47.7^{\mathrm{c}}$ & $48^{\mathrm{c}}$ & $49.3^{c}$ & $59.7^{\mathrm{bc}}$ & $\mathrm{ns}$ & ns & $\mathrm{ns}$ \\
\hline Average & 47.1 & 51.2 & 57.2 & 54.5 & 57.4 & 65.7 & & & \\
\hline
\end{tabular}

$\mathrm{D}_{1}$ : Seed drying method; $\mathrm{D}_{2}$ : Pod drying method, DAF: Days after flowering. $\mathrm{F}_{1}=$ control $\left(150 \mathrm{mg} \mathrm{L}^{-1} \mathrm{~N} ; 150 \mathrm{mg}\right.$ $\left.\mathrm{L}^{-1} \mathrm{P} ; 150 \mathrm{mg} \mathrm{L}^{-1} \mathrm{~K}\right) ; \mathrm{F}_{2}=300 \mathrm{mg} \mathrm{L}^{-1} \mathrm{~N} ; 150 \mathrm{mg} \mathrm{L}^{-1} \mathrm{P} ; 150 \mathrm{mg} \mathrm{L}^{-1} \mathrm{~K} ; \mathrm{F}_{3}=450 \mathrm{mg} \mathrm{L}^{-1} \mathrm{~N} ; 150 \mathrm{mg} \mathrm{L}^{-1} \mathrm{P} ; 150 \mathrm{mg} \mathrm{L}^{-1}$ $\mathrm{K}$.

ns: non- significant; * significant at 5-\% $(\mathrm{P}<0.05)$. 
Table 6. Effect of fertilizer on seed germination percentage of cv. 'Boyiatiou' in relation to drying method and time of harvest

\begin{tabular}{|c|c|c|c|c|c|c|c|c|c|}
\hline & & & & & & & \multicolumn{3}{|c|}{ Cultivar: Boyiatiou } \\
\hline Plant part & Upper & & & & & & & & \\
\hline Drying method & $\mathrm{D}_{1}$ & & & $\mathrm{D}_{2}$ & & & $\mathrm{~F}_{1}$ & $\mathrm{~F}_{2}$ & $\mathrm{~F}_{3}$ \\
\hline Pod harvesting time & $\mathrm{F}_{1}$ & $\mathrm{~F}_{2}$ & $\mathrm{~F}_{3}$ & $\mathrm{~F}_{1}$ & $\mathrm{~F}_{2}$ & $\mathrm{~F}_{3}$ & $\mathrm{D}_{1} * \mathrm{D}_{2}$ & $\mathrm{D}_{1} * \mathrm{D}_{2}$ & $\mathrm{D}_{1} * \mathrm{D}_{2}$ \\
\hline $30 \mathrm{DAF}$ & $46.2^{\mathrm{bc}}$ & $41^{\mathrm{c}}$ & $41^{\mathrm{c}}$ & $40.7^{\mathrm{c}}$ & $42^{\mathrm{c}}$ & $45^{\mathrm{c}}$ & ns & ns & ns \\
\hline $35 \mathrm{DAF}$ & $51.5^{\mathrm{ab}}$ & $48.3^{\mathrm{b}}$ & $51^{\mathrm{b}}$ & $51.3^{\mathrm{b}}$ & $52.7^{\mathrm{b}}$ & $57.7^{\mathrm{b}}$ & ns & $\mathrm{ns}$ & ns \\
\hline $40 \mathrm{DAF}$ & $59.5^{\mathrm{a}}$ & $64.3^{\mathrm{a}}$ & $66.7^{\mathrm{a}}$ & $62.7^{\mathrm{a}}$ & $71^{\mathrm{a}}$ & $74^{\mathrm{a}}$ & ns & ns & ns \\
\hline $50 \mathrm{DAF}$ & $42^{c}$ & $38.3^{\mathrm{c}}$ & $38.3^{\mathrm{d}}$ & $35.3^{\mathrm{d}}$ & $43.3^{\mathrm{c}}$ & $53.7^{\mathrm{b}}$ & ns & ns & ns \\
\hline Average & 49.8 & 47.9 & 49.2 & 47.5 & 52.2 & 57.6 & & & \\
\hline
\end{tabular}

$\mathrm{D}_{1}$ : Seed drying method; $\mathrm{D}_{2}$ : Pod drying method, DAF: Days after flowering. $\mathrm{F}_{1}=\operatorname{control}\left(150 \mathrm{mg} \mathrm{L}^{-1} \mathrm{~N} ; 150 \mathrm{mg}\right.$ $\left.\mathrm{L}^{-1} \mathrm{P} ; 150 \mathrm{mg} \mathrm{L}^{-1} \mathrm{~K}\right) ; \mathrm{F}_{2}=300 \mathrm{mg} \mathrm{L}^{-1} \mathrm{~N} ; 150 \mathrm{mg} \mathrm{L}^{-1} \mathrm{P} ; 150 \mathrm{mg} \mathrm{L}^{-1} \mathrm{~K} ; \mathrm{F}_{3}=450 \mathrm{mg} \mathrm{L}^{-1} \mathrm{~N} ; 150 \mathrm{mg} \mathrm{L}^{-1} \mathrm{P} ; 150 \mathrm{mg} \mathrm{L}^{-1}$ $\mathrm{K}$.

ns: non- significant; * significant at 5-\% $(\mathrm{P}<0.05)$.

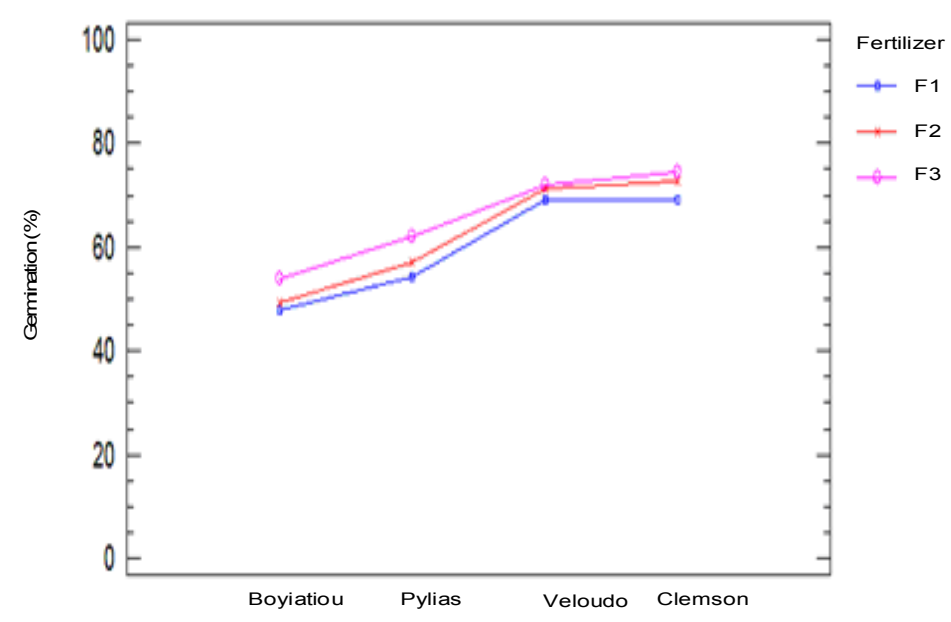

Figure 5. Effect of fertilizer on seed germination percentage for seed drying method

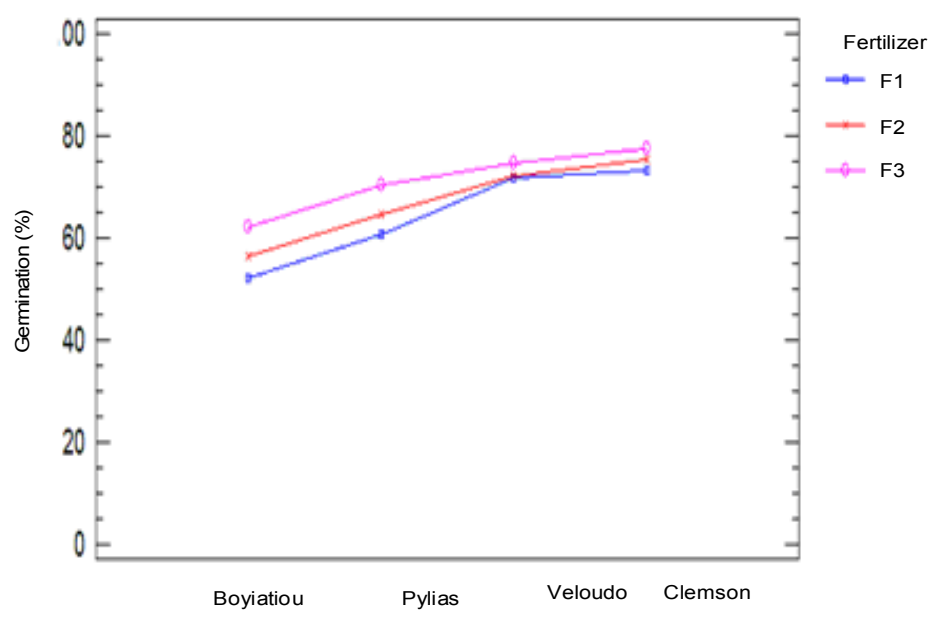

Figure 6. Effect of fertilizer on seed germination percentage for pod drying method 
El Balla et al. (2011) reported that germination percentage and hard seeds percentage were significantly affected by cultivar and seed maturity of okra plants cultivated for two growing seasons. Bhatt and Srinivasa Rao (1998) also reported a significant reduction for seed germination of various cultivars of okra plants grown under field conditions compared with plants cultivated under controlled conditions. For some cultivars, the occurrence of hardseedness is more frequent when the pods remain on the plant for longer time periods until harvest (Luis Felip et al., 2010).

The results for moisture content showed that cv. 'Boyiatiou' and 'Veloudo' had higher percentage of hard seeds and lower seed moisture content than cv. 'Pylias' and 'Clemson' (Table 7). Moisture content of seeds did not differ significantly among the various cultivars, whereas seeds dried after harvesting inside pods (slow drying method) had a significantly lower moisture content than seeds dried after being removed from pods (fast drying method) (Table 7).

Table 7. Effect of fertilizer on seedmoisture contentpercentage (MC)in relation to drying methodsand cultivar

\begin{tabular}{llll}
\hline Fertilizer & Cultivar & Seed drying MC\% & Pod drying MC \% \\
\hline $\mathrm{F}_{1}$ & Boyiatiou & 20.9 & 11.0 \\
& Veloudo & 27.5 & 11.1 \\
& Pylias & 39.2 & 11.5 \\
& Clemson & 36.6 & 11.1 \\
\hline $\mathrm{F}_{2}$ & Boyiatiou & 22.7 & 11.3 \\
& Veloudo & 25.3 & 11.1 \\
& Pylias & 39.9 & 12.9 \\
& Clemson & 38.3 & 11.5 \\
\hline $\mathrm{F}_{3}$ & Boyiatiou & 23.2 & 12.3 \\
& Veloudo & 27.4 & 11.6 \\
& Pylias & 41.1 & 11.4 \\
& Clemson & 31.5 & 11.8 \\
\hline ANOVA & 20.6 & 16.6 \\
Main effects & 7086.3 & 8.6 \\
Fertilizer (F) & 191.2 & 11.2 \\
Cultivar (C) & & \\
Interactions (FxC) & & \\
\hline
\end{tabular}

$\mathrm{F}_{1}=$ control $\left(150 \mathrm{mg} \mathrm{L}^{-1} \mathrm{~N} ; 150 \mathrm{mg} \mathrm{L}^{-1} \mathrm{P} ; 150 \mathrm{mg} \mathrm{L}^{-1} \mathrm{~K}\right) ; \mathrm{F}_{2}=300 \mathrm{mg} \mathrm{L}^{-1} \mathrm{~N} ; 150 \mathrm{mg} \mathrm{L}^{-1} \mathrm{P} ; 150 \mathrm{mg} \mathrm{L}^{-1} \mathrm{~K} ; \mathrm{F}_{3}=450$ $\mathrm{mg} \mathrm{L}^{-1} \mathrm{~N} ; 150 \mathrm{mg} \mathrm{L}^{-1} \mathrm{P} ; 150 \mathrm{mg} \mathrm{L}^{-1} \mathrm{~K}$.

Demir et al. (2001) suggested that there is a direct relationship between the seed moisture content and the delayed permeability of seeds with variances between cultivars and seed moisture content. El Balla et al. (2011) reported that seed moisture content was significantly affected by cultivar and seed maturity; seed moisture content within each cultivar was significantly decreased with seed maturity. Similar results were reported by Quinlivan (1971), Ellis et al. (1985) and El Balla et al. (1989) who suggested that seed moisture content is of major importance for the development of hard seeds, whereas the critical level of moisture content required for germination varied among cultivars.

\subsection{Effect of Fertilizer on Seed Germination of Different Parts of Plant}

The effect of fertilizer on germination of seeds harvested from different parts of plant showed that for all cultivars seeds from the middle part of plant and for both drying methods showed the highest germination percentage when $450 \mathrm{mg} \mathrm{L}^{-1} \mathrm{~N}$ were applied (Figures 7 and 8). For cv. 'Boyiatiou', 'Veloudo' and 'Clemson', seeds from the lower part of the plant (Tables 2, 8, and 9) and for cv. 'Pylias' seeds from the upper part of the plant had higher seed germination percentage, when seeds were dried with the fast drying method (Table 10); whereas for pod drying method seed germination percentage was higher when seeds were harvested from the lower part of the plant (cv. 'Boyiatiou' and 'Clemson') (Tables 2 and 9), the middle part of the plant (cv. 'Veloudo') (Table 4) and the upper part of the plant (cv 'Pylias') (Table 10). 


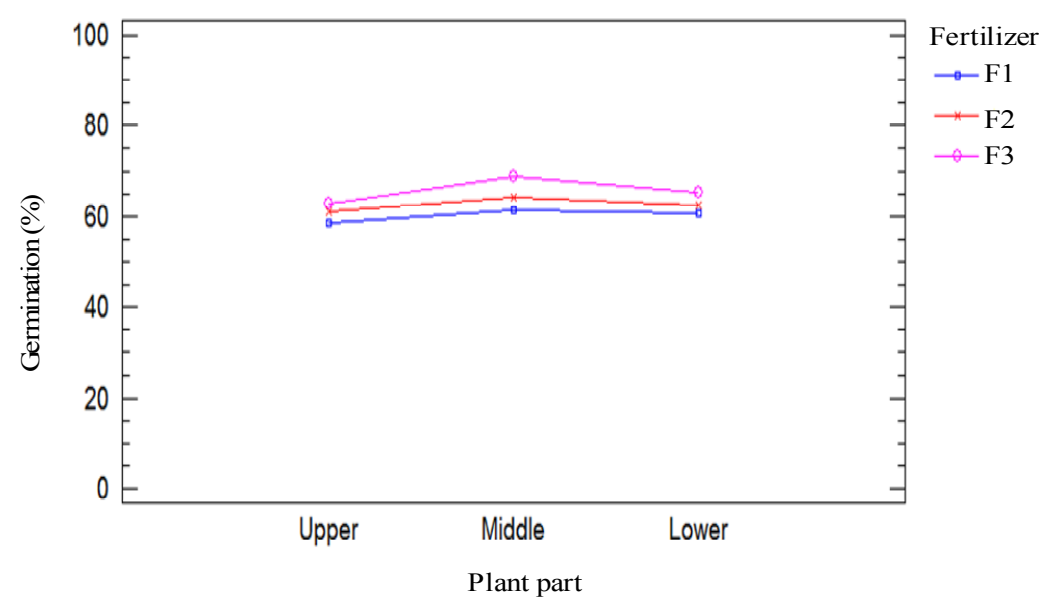

Figure 7. Effect of fertilizer on seed germination percentage for seed drying methodin relation to plant part

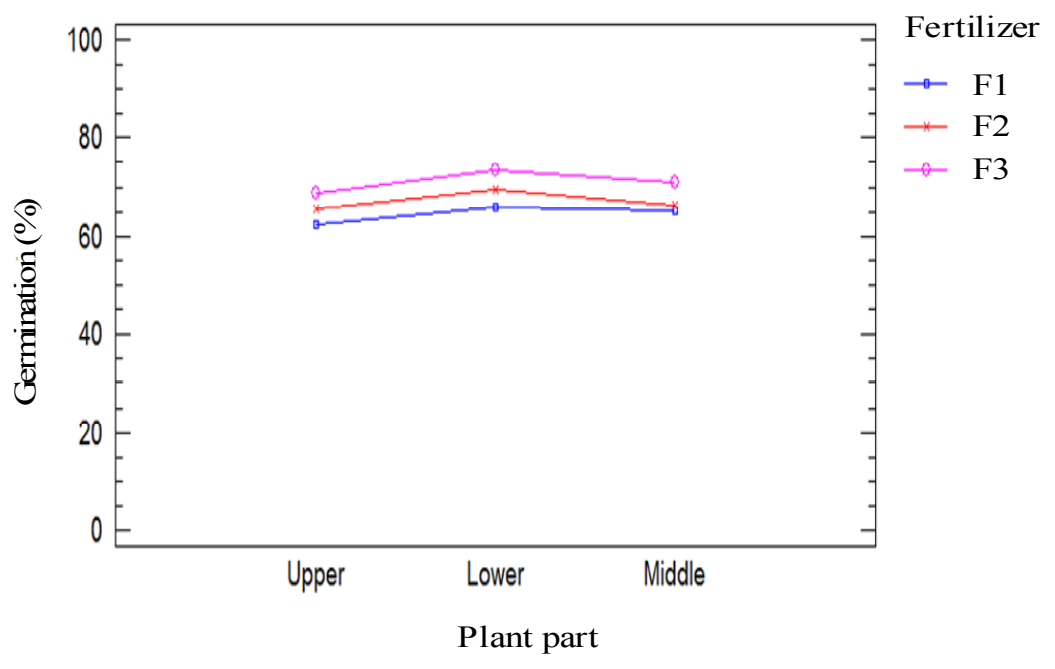

Figure 8. Effect of fertilizer on seed germination percentage for pod drying methodin relation to plant part

Table 8. Effect of fertilizer on seed germination percentage of cv. 'Veloudo' in relation to drying method and plant part

\begin{tabular}{|c|c|c|c|c|c|c|c|c|c|}
\hline & & & & & & & \multicolumn{3}{|c|}{ Cultivar: Veloudo } \\
\hline Plant part & Lowe & & & & & & & & \\
\hline Drying method & $\mathrm{D}_{1}$ & & & $\mathrm{D}_{2}$ & & & $\mathrm{~F}_{1}$ & $\mathrm{~F}_{2}$ & $\mathrm{~F}_{3}$ \\
\hline Pod harvesting time & $\mathrm{F}_{1}$ & $\mathrm{~F}_{2}$ & $\mathrm{~F}_{3}$ & $\mathrm{~F}_{1}$ & $\mathrm{~F}_{2}$ & $\mathrm{~F}_{3}$ & $\mathrm{D}_{1} * \mathrm{D}_{2}$ & $\mathrm{D}_{1} * \mathrm{D}_{2}$ & $\mathrm{D}_{1} * \mathrm{D}_{2}$ \\
\hline $30 \mathrm{DAF}$ & $46.3^{\mathrm{d}}$ & $52^{\mathrm{bd}}$ & $51^{\mathrm{d}}$ & $48^{\mathrm{c}}$ & $55^{\mathrm{bcd}}$ & $55^{\mathrm{d}}$ & ns & ns & ns \\
\hline $35 \mathrm{DAF}$ & $50^{c}$ & $54^{\mathrm{b}}$ & $55^{\mathrm{c}}$ & $56^{\mathrm{b}}$ & $57.3^{\mathrm{bcd}}$ & $60.7^{\mathrm{c}}$ & ns & $\mathrm{ns}$ & ns \\
\hline $40 \mathrm{DAF}$ & $74.3^{\mathrm{a}}$ & $82.3^{\mathrm{a}}$ & $76^{\mathrm{a}}$ & $80^{\mathrm{a}}$ & $85^{\mathrm{a}}$ & $87.3^{\mathrm{a}}$ & ns & ns & ns \\
\hline $50 \mathrm{DAF}$ & $56^{\mathrm{b}}$ & $51^{\mathrm{bd}}$ & $65^{\mathrm{b}}$ & $59.7^{\mathrm{b}}$ & $60^{\mathrm{bcd}}$ & $76.7^{\mathrm{b}}$ & ns & ns & ns \\
\hline Average & 56.6 & 59.8 & 61.7 & 60.9 & 64.3 & 69.9 & & & \\
\hline
\end{tabular}

$\mathrm{D}_{1}$ : Seed drying method; $\mathrm{D}_{2}$ : Pod drying method, DAF: Days after flowering. $\mathrm{F}_{1}=$ control $\left(150 \mathrm{mg} \mathrm{L}^{-1} \mathrm{~N} ; 150 \mathrm{mg}\right.$ $\left.\mathrm{L}^{-1} \mathrm{P} ; 150 \mathrm{mg} \mathrm{L}^{-1} \mathrm{~K}\right) ; \mathrm{F}_{2}=300 \mathrm{mg} \mathrm{L}^{-1} \mathrm{~N} ; 150 \mathrm{mg} \mathrm{L}^{-1} \mathrm{P} ; 150 \mathrm{mg} \mathrm{L}^{-1} \mathrm{~K} ; \mathrm{F}_{3}=450 \mathrm{mg} \mathrm{L}^{-1} \mathrm{~N} ; 150 \mathrm{mg} \mathrm{L}^{-1} \mathrm{P} ; 150 \mathrm{mg} \mathrm{L}^{-1}$ $\mathrm{K}$.

ns: non- significant; * significant at 5-\% $(\mathrm{P}<0.05)$. 
Table 9. Effect of fertilizer on seed germination percentage of cv. 'Clemson' in relation to drying method and plant part

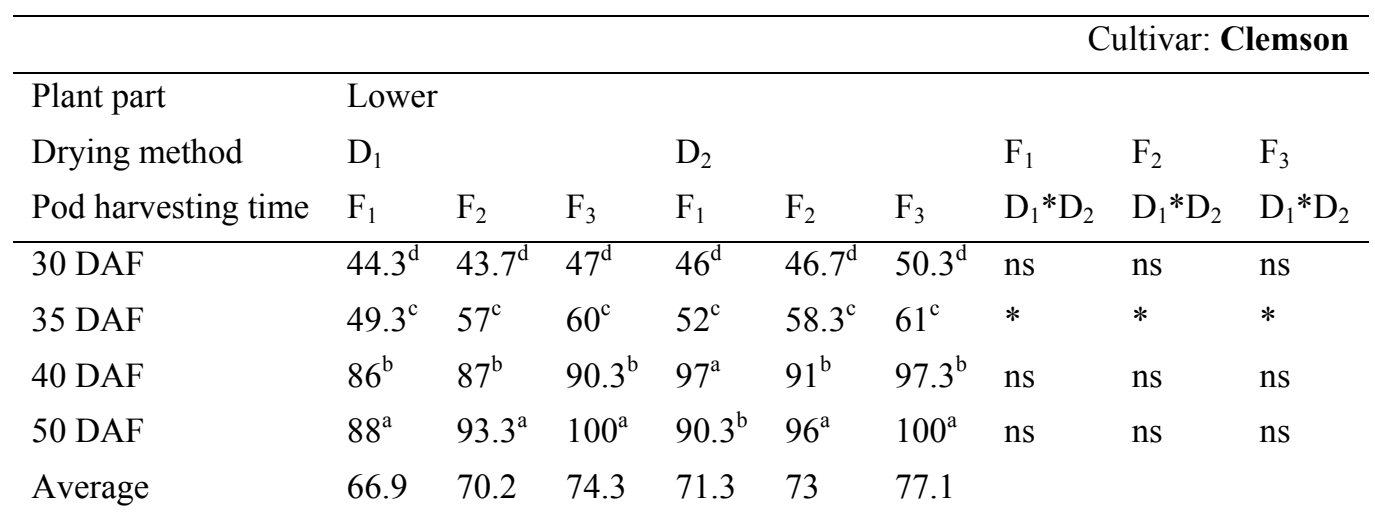

$\mathrm{D}_{1}$ : Seed drying method; $\mathrm{D}_{2}$ : Pod drying method, DAF: Days after flowering. $\mathrm{F}_{1}=\operatorname{control}\left(150 \mathrm{mg} \mathrm{L}^{-1} \mathrm{~N} ; 150 \mathrm{mg}\right.$ $\left.\mathrm{L}^{-1} \mathrm{P} ; 150 \mathrm{mg} \mathrm{L}^{-1} \mathrm{~K}\right) ; \mathrm{F}_{2}=300 \mathrm{mg} \mathrm{L}^{-1} \mathrm{~N} ; 150 \mathrm{mg} \mathrm{L}^{-1} \mathrm{P} ; 150 \mathrm{mg} \mathrm{L}^{-1} \mathrm{~K} ; \mathrm{F}_{3}=450 \mathrm{mg} \mathrm{L}^{-1} \mathrm{~N} ; 150 \mathrm{mg} \mathrm{L}^{-1} \mathrm{P} ; 150 \mathrm{mg} \mathrm{L}^{-1}$ $\mathrm{K}$.

ns: non- significant; * significant at 5-\% $(\mathrm{P}<0.05)$.

Table 10. Effect of fertilizer on seed germination percentage of cv. 'Pylias' in relation to drying method and plant part

\begin{tabular}{|c|c|c|c|c|c|c|c|c|c|}
\hline & & & & & & & & \multicolumn{2}{|c|}{ Cultivar: Pylias } \\
\hline Plant part & Upper & & & & & & & & \\
\hline Drying method & $\mathrm{D}_{1}$ & & & $\mathrm{D}_{2}$ & & & $\mathrm{~F}_{1}$ & $\mathrm{~F}_{2}$ & $\mathrm{~F}_{3}$ \\
\hline Pod harvesting time & $\mathrm{F}_{1}$ & $\mathrm{~F}_{2}$ & $\mathrm{~F}_{3}$ & $\mathrm{~F}_{1}$ & $\mathrm{~F}_{2}$ & $\mathrm{~F}_{3}$ & $\mathrm{D}_{1} * \mathrm{D}_{2}$ & $\mathrm{D}_{1} * \mathrm{D}_{2}$ & $\mathrm{D}_{1} * \mathrm{D}_{2}$ \\
\hline $30 \mathrm{DAF}$ & $51^{d}$ & $52^{\mathrm{c}}$ & $54^{\mathrm{d}}$ & $57^{\mathrm{b}}$ & $51.3^{\mathrm{d}}$ & $56^{\mathrm{d}}$ & $*$ & ns & ns \\
\hline $35 \mathrm{DAF}$ & $60^{\mathrm{c}}$ & $58^{\mathrm{c}}$ & $62.3^{\mathrm{c}}$ & $59.7^{\mathrm{b}}$ & $60^{\mathrm{c}}$ & $64.3 \mathrm{c}$ & ns & ns & ns \\
\hline $40 \mathrm{DAF}$ & $87^{\mathrm{a}}$ & $92.7^{\mathrm{a}}$ & $99^{\mathrm{a}}$ & $83.3^{\mathrm{a}}$ & $94^{\mathrm{a}}$ & $98.3^{\mathrm{a}}$ & * & $*$ & ns \\
\hline $50 \mathrm{DAF}$ & $71.7^{\mathrm{b}}$ & $82^{\mathrm{b}}$ & $74^{\mathrm{b}}$ & $80.3^{\mathrm{a}}$ & $85.7^{\mathrm{b}}$ & $80^{\mathrm{b}}$ & ns & ns & ns \\
\hline Average & 67.4 & 71.1 & 72.3 & 70.0 & 72.7 & 74.6 & & & \\
\hline
\end{tabular}

D1: Seed drying method; D2: Pod drying method, DAF: Days after flowering. $\mathrm{F}_{1}=\operatorname{control}\left(150 \mathrm{mg} \mathrm{L}^{-1} \mathrm{~N} ; 150 \mathrm{mg}\right.$ $\left.\mathrm{L}^{-1} \mathrm{P} ; 150 \mathrm{mg} \mathrm{L}^{-1} \mathrm{~K}\right) ; \mathrm{F}_{2}=300 \mathrm{mg} \mathrm{L}^{-1} \mathrm{~N} ; 150 \mathrm{mg} \mathrm{L}^{-1} \mathrm{P} ; 150 \mathrm{mg} \mathrm{L}^{-1} \mathrm{~K} ; \mathrm{F}_{3}=450 \mathrm{mg} \mathrm{L}^{-1} \mathrm{~N} ; 150 \mathrm{mg} \mathrm{L}^{-1} \mathrm{P} ; 150 \mathrm{mg} \mathrm{L}^{-1}$ $\mathrm{K}$.

ns: non- significant; * significant at 5-\% $(\mathrm{P}<0.05)$.

Similar results were reported by Yadav et al. (2001) who found that seed germination was higher for fruits harvested from lower positions of okra plants grown under semiarid conditions. Naik et al. (2004) also reported that the quality of okra seeds harvested from fruits set up to the $8^{\text {th }}$ node was superior, when plants were grown under tropical conditions at Bangalore, India. The study of the seed moisture content from different parts of the plant showed that seeds from the upper part of the plant had higher seed moisture content when seed drying method was applied, whereas for pod drying method seed moisture content was higher for seeds from the middle part of the plant (Table 11). Mohammadi et al. (2011) also reported that seeds from the middle part of the plant had higher seed moisture content at the time of harvest. 
Table 11. Effect of fertilizer on seed moisture content percentage in relation to drying method and plant part

\begin{tabular}{llll}
\hline Fertilizer & Plant part & Seed drying MC\% & Pod drying MC \% \\
\hline \multirow{3}{*}{$\mathrm{F}_{1}$} & Upper & 35.0 & 11.1 \\
& Middle & 33.8 & 11.7 \\
& Lower & 24.4 & 10.7 \\
\hline \multirow{2}{*}{$\mathrm{F}_{2}$} & Upper & 33.9 & 12.1 \\
& Middle & 34.2 & 11.0 \\
& Lower & 26.5 & 11.9 \\
\hline \multirow{2}{*}{$\mathrm{F}_{3}$} & Upper & 35.1 & 11.0 \\
& Middle & 30.1 & 12.4 \\
\hline ANOVA & Lower & 27.3 & 11.9 \\
Main effects & 20.6 & 16.6 \\
Fertilizer (F) & 2911.0 & 2.9 \\
Plant part (P) & 177.0 & 23.9 \\
Interactions (FxP) & & \\
\hline
\end{tabular}

F1= control (150 mg L-1 N; 150 mg L-1 P; 150 mg L-1 K); F2= 300 mg L-1 N; 150 mg L-1 P; 150 mg L-1 K; F3= 450 mg L-1 N; 150 mg L-1 P; 150 mg L-1 K.

\section{Conclusion}

The application of $450 \mathrm{mg} \mathrm{L}^{-1} \mathrm{~N}$ increased seed germination percentage for both drying methods. The highest seed germination percentage was found when pod drying method was applied. For both drying methods, the application of $450 \mathrm{mg} \mathrm{L}^{-1} \mathrm{~N}$ had a more profound effect on seed germination when seeds were harvested at 40 days after flowering (DAF). For all cultivars and for both drying methods, the application of $450 \mathrm{mg} \mathrm{L}^{-1} \mathrm{~N}$ resulted in higher seed germination percentage. Regarding the effect of cultivar, cv. 'Boyiatiou' had higher percentage of hard seeds in comparison to other cultivars, especially when $150 \mathrm{mg} \mathrm{L}^{-1} \mathrm{~N}$ were applied. In addition, for all cultivars and drying methods, seeds from the middle part of the plant had the highest seed germination percentage when $450 \mathrm{mg} \mathrm{L}^{-1} \mathrm{~N}$ were applied.

\section{References}

Amjad, M., Akbar A. M., \& Hussain, S. (2001). Effect of different sowing dates and various doses of fertilizer on juvenility and productivity of okra. Pak. J. Agri. Sci., 38(1-2), 29-32.

Anjum, M. A., \& Amjad, M. (1999). Response of okra (Abelmoschus esculentus L. Moench.) to different levels of N, P and K fertilizers. Pak. J. BioI. Sci., 2, 794-796. http://dx.doi.org/10.3923/pjbs.1999.794.796

Auld, D. L., Bettis, B. L., Crock, J. E., \& Kephart, D. (1988). Planting date and temperature effects on germination, and seed yield of Chickpea. Agron. J., 80, 909-914. http://dx.doi.org/10.2134/agronj1988.00021962008000060014x

Baskin, J. M., \& Baskin, C. C. (1998). Seeds: Ecology, Biogeography and Evolution of Dormancy and Germination. San Diego, CA: Academic Press.

Bhatt, R. M., \& Srinivasa Rao, N. K. (1998). Germination response to fruit position and temperature in okra (Abelmoschus esculenthus (L.)). Indian J. Hort., 55, 81-84.

Black, M., Bewley, J. D., \& Halmer, P. (2006). The encyclopedia of seeds: science, technology and uses. Wallingford, UK: CAB International.

Budy, J., Evans, R., \& Young, J. (1986). Understanding Seed Handling for Germination. Arlington, VA: Volunteers in Technical Assistance.

Castro, M. M., Godoy, A. R., \& Cardoso, A. I. I. (2008). Okra seed quality as a function of age and fruit post harvest rest. Cienc. Agrotec., 32(5), 1491-1495. http://dx.doi.org/10.1590/S1413-70542008000500020

Chauhan, K. S., \& Bhandari, Y. M. (1971). Pod development and germination studies in okra (Abelmoschus esculenthus (L.) Moench.). Indian J. Agri. Sci., 41(10), 852-856.

Copeland, L. O., \& McDonald, M. B. (2001). Principles of seed science and technology. Boston: Kluwer Academic Publishers. http://dx.doi.org/10.1007/978-1-4615-1619-4 
Demir, I. (1997). Occurrence of hardseededness in relation to seed development in okra (Abelmoschus esculentus (L.) Moench). Plant Var. Seeds, 10(1), 7-13.

Demir, I. (2001). The effects of heat treatment on hardseedness of serially harvested okra seed lots at optimum and low temperatures. Sci. Hortic., 89, 1-7. http://dx.doi.org/10.1016/S0304-4238(00)00216-8

Egley, G. H., \& Elmore, C. D. (1987). Germination and the potential persistence of weedy and domestic okra (Abelmoschus esculentus (L.) Moench.) seeds. Weed Sci., 35, 45-51.

El Balla, M. M. A., Saidahmed, A. I., \& Makkawi, M. (2011). Effect of moisture content and maturity on hardseededness and germination in okra (Abelmoschus esculentus L. Moench). Int. J. Plant Physi. Biochem., 3(6), 102-107.

Ellis, R. H., Hong, T. D., \& Roberts, E. H. (1985). Handbook of seed technology for gene banks. Compendium of specific germination information and test recommendations. IBPGR, Rome, II, 211-667.

Ewete, F. K. (1980). Quality seed production in okra (Abelmoschus esculenthus (L.) Moench). Vegetables Hot Humid Trop., 5, 39-44.

Geneve, R. L. (1998). Seed dormancy in commercial vegetable and flower species. Seed Technol., 20, 236-250.

Hilhorst, H. W., \& Toorop, P. E. (1997). Review on dormancy, germinability, and germination in crop and weed seeds. Adv. Agron., 61, 111-165. http://dx.doi.org/10.1016/S0065-2113(08)60663-X

ISTA (2009). International rules for seed testing. Seed Sci. Technol. International Seed Testing Association, Switzerland.

Kanwar, J. S., \& Saimbhi, M. S. (1987). Pod maturity and seed quality in okra (Abelmoschus esculenthus (L.) Moench). Punjab Hort. J., 27(3/4), 234-238.

Lenka, P. C., Das, D. K., \& Mishra, H. N. (1989). Effect of nitrogen and phosphorus on seed yield of Bhindi cv. Parbhanikranti. J. Agric. Res., 2, 125-127.

Luis Felipe, V. P., Antonio, A. D. L., \& Francisco Antonio, P. (2010). Germination and hardseedness of seeds in okra elite lines. Hortic. Bras., 28(2), 232-235. http://dx.doi.org/10.1590/S0102-05362010000200017

Malik, Y. S., Singh, N., Nehra, B. K., Khurana, S. C., Dahiya, M. S., \& Singh, N. (2000). Okra seed quality as influenced by position of pod on mother plant, ripening stage of pod and ambient storage conditions. Haryana J. Hort. Sci., 29, 229-232.

Mmolawa, O. B. (1987). Germination and dormancy of meadow foam seed. M.Sc. thesis, Oregon State University, USA.

Mishra, R. K., \& Singh, G. (2005). Effeect of sources of nutrients on performance of okra (Abelmschus esculentus (L.) Moench). Sri Lankan J. Agric. Sci., 42, 52-57.

Mohammadi, G., Ebrahim, M. K., \& Mohammad, B. A. (2011). Differential Responses for Harvesting Times and Storage on Hardness of Different Varieties of Okra. Not. Sci. Biol., 3(4), 117-122.

Muhammad, A., Muhammad, A. A., \& Sajid, H. (2001). Effect of different sowing dates and various doses of fertilizer on juvenility and productivity of okra. Pakistan J. Agric. Sci., 38(1-2), 29-32.

Naik, L. B., Vogeesha, H. S., Bhanuprakash, K., \& Padmini, K. (2004). Production of open pollinated seeds in okra. In: Annual Report, 2003-04. Indian Institute of Horticultural Research, Bangalore, India.

Neupane, P. R., Ghimire, A. J., \& Khanala, R. (1991). Seed research on summer vegetable crops (sweet pepper and okra) at PAC. Tech. Pap. Pakhribas Agril. Cent., 144, 12.

Passam, H. C., Akoumianakis, K., \& Sarigiannidi, A. (1998). The effect of time of sowing on the production of okra (Hibiscus esculentus L.) seed in the Mediterranean region. Plant Var. Seeds, 12(1), 145-150.

Prabhakar, B. S., Hegde, D. M., Srinivas, K., \& Doijode, S. C. (1985). Seed quality and productivity of okra in relation to nodal position of pod. S. Indian Hort., 33(2), 115-117.

Quinlivan, B. J. (1971). Seed coat impermeability in legumes. J. Aust. Inst. Agric. Sci., 37, 283-295.

Saif, U. R. R. K., Muhammad, Y., Muhammad, A., \& Muhammad, A. (2008). Response of okra (Hibiscus esculentus L.) to soil given encapsulated calcium carbide. Pak. J. Bot., 40(1), 175-181.

Setubal, J. W., Zanin, A. C. W., \& Nakagawa, J. (1994). Efeitos de métodos de colheita eda localização dos frutos na planta sobre aocorrência de sementes duras em quiabeiro (Abelmoschus esculentus (L.) Moench). Sci. Agric., 51, 490-493. http://dx.doi.org/10.1590/S0103-90161994000300019 
Setubal, N. J., Zanin, A. C. W., \& de Sementes de Quiaberio II. (1998). Effects of fruit age, drying method and condition on seed quality of okra. Pesqui. Agropecu. Brasil., 33(7), 1185-1189.

Standifer, L. C., Wilson, P. W., \& Drummond, A. (1989). The effect of seed moisture content on hardseededness and germination in four cultivars of okra (Abelmoschus esculentus (L.) Moench). Plant Var. Seeds, 2, 149-154.

Thakur, M. R., \& Arora, S. K. (1993). Okra. In: T. K. Bose, M. G. Som, \& J. Kabir (Eds.), Vegetable Crops (p. 711). Naya Prokash, Calcutta.

Wiese, A. M., \& Binning, L. K. (1987). Calculating the threshold temperature of development for weeds. Weed Sci., 35, 177-179.

Yadav, S. K., Dhankar, B. S., Deshwal, D. P., \& Tomer, R. P. S. (2001). Effect of sowing date and plant geometry on seed production and quality of okra (Abelmoschus esculenthus (L.) Moench) cv. Varsha Uphar. Seed Res., 29(2), 149-152. 